\title{
Promoting Engineering Education as a Career: A Generational Approach
}

\author{
James Morgan, Princeton University Plasma Physics Laboratory \\ Beverly Davis, Purdue University
}

\begin{abstract}
Currently, there is a fundamental paradigm shift in society with regards to attitudes towards the sciences. In higher education, this shift is especially noticeable within engineering programs. Many educators are encouraged to shift the traditional teaching focus and concentrate on student learning. A disturbing trend finds many young people are unaware what a career in engineering entails, are unaware of the job opportunities afforded to them with an engineering degree, or for numerous reasons decide early on in their education that engineering is not for them. The number of earned degrees in engineering and computer sciences grew sharply in the early 1980s, peaked in 1986, and then dropped precipitously before leveling off in the 1990s [2]. In addition, a 2001 National Science Foundation/Division of Science Resources Statistics, Survey of Graduate Students and Post-doctorates found that graduate student enrollment in the sciences and engineering fields have dropped significantly between 1994 and 2001. Clearly, engineering as a profession needs to promote itself on numerous levels. One avenue available is to seek to understand and promote engineering to the future generations, or specifically the millennial generation (Born in the 1980's-2000's).

The different learning styles, preferred by "Millennials" should be incorporated into the engineering curriculum and adapted for different methods of information and instruction delivery. The new technological environment is resources-based and rich in data and information and promotes learning through active task performance rather than more or less passive attendance at lectures. Research has shown that Millennials respond well to anything experiential. The techno-savvy millennial generation, as a whole, will be motivated by opportunities for creativity and challenging learning environments. The open-ended access to information, the ability to tailor the paths to learning, and the possibility of continuous and instantaneous performance assessment, offer a great deal of flexibility both in the design of curricula as well as in the method of delivery.

Currently, the oldest of the millennial generation is in college while the youngest is entering grade school. To be successful in promoting engineering to this cohort, educators must understand the millennial generation, appeal to their motivations when promoting engineering as a career choice, and offer a learning environment designed for their learning style. This paper will offer suggestions on promoting engineering as a career by focusing on generational learning styles and preferences. In addition, the future Millennial generation should be educated on engineering degrees, career choices, and future job opportunities. Promotion of career choices in engineering to this generation is critical for future success.
\end{abstract}

\section{Introduction}

Proceedings of the 2005 American Society for Engineering Education Annual Conference and Exposition. Copyright (C) 2005 American Society for Engineering Education 
The Millennial generation (born 1980's-2000's) has been labeled many things; Echo Boomers, Y2 Generation, Internet Generation, Cyber Generation, Nintendo Generation and the Net Generation are just a few. As this generation slowly trickles into the workforce, it is critical to consider how this will affect the future of engineering education. A disturbing trend finds many of these young people are unaware what a career in engineering entails, are unaware of the job opportunities afforded to them with an engineering degree, or for numerous reasons decide early on in their education that engineering is not for them. Unfortunately, many engineering programs in this country are seeing an alarming decline in enrollments. Currently, the oldest of the millennial generation is in college while the youngest is entering grade school. To be successful in promoting engineering to this cohort, educators must understand the millennial generation, appeal to their motivations when promoting engineering as a career choice, and offer a learning environment designed for their learning style. Educators will be tasked with appealing to students and revitalizing the image of engineering education if we are to disrupt the negative trend of declining enrollments in engineering. These declining numbers should be of concern to all engineering educators: For example, the number of earned degrees in engineering and computer sciences grew sharply in the early 1980s, peaked in 1986, and then dropped precipitously before leveling off in the 1990s [2]. As many millennials were entering the world, engineering and science education enrollment numbers were already in a downward spiral. As our focus is now on this new generation, many of the identifiers are telling. They are linked to the digital age and referred to as the cyber, Nintendo, and Net generation. It is increasingly apparent that their learning styles and interests will be linked to many characteristics associated with the digital age. As we look to the future of engineering and science education, generational learning styles and preferences must be considered to achieve optimal learning outcomes. Moreover, the future millennial generation should be educated on engineering and science degrees, career choices, and future job opportunities. As suggested by the above statistics, promotion of career choices in engineering and the sciences to the millennial generation is critical for future success.

\section{Engineering and Science Careers}

According to the U.S. Department of Labor, the overall unemployment rate for engineers increased from 3.6 percent in the first quarter of 2002 to 4.0 percent in the second quarter. The rate for electrical and electronics engineers rose during the same period from 4.1 percent to 4.8 percent.

Many engineers work on long-term research and development projects or in other activities that continue even during economic slowdowns. In industries such as electronics and aerospace, however, large cutbacks in defense expenditures and government research and development funds in the past, as well as the trend toward contracting out engineering work to engineering services firms, both domestic and foreign, have resulted in significant layoffs of engineers. Some would say that engineers are being treated as expendable labor, especially when economic times are bad.

In 2002 engineers held 1.5 million jobs. The following tabulation shows the distribution

Proceedings of the 2005 American Society for Engineering Education Annual Conference and Exposition. Copyright (C) 2005 American Society for Engineering Education 
of employment by engineering specialty.

Total, all engineers - 1,478,000 (100\%)

Electrical and electronics - 292,000 (19.8\%)

Civil - 228,000 (15.4\%)

Mechanical - 215,000 (14.5\%)

Industrial, including health and safety - 194,000 (13.1\%)

Aerospace - 78,000 (5.3\%)

Computer hardware - 74,000 (5.0\%)

Environmental - 47,000 (3.2\%)

Chemical - 33,000 (2.2\%)

Materials - 24,000 (1.6\%)

Nuclear - $16,000(1.1 \%)$

Petroleum - $14,000(0.9 \%)$

Biomedical - 7,600 (0.5\%)

Mining and geological, including mining safety - 5,200 (0.4\%)

Marine engineers and naval architects - 4,900 (0.3\%)

Agricultural - 2,900 (0.2\%)

All other engineers - 243,000 (16.4\%)

Overall engineering employment is expected to grow more slowly than the average for all occupations over the 2002-2012 period. Engineers tend to be concentrated in slowgrowing manufacturing industries, a factor which tends to hold down their employment growth. Also, many employers are increasing their use of engineering services performed in other countries. Despite this, overall job opportunities in engineering are expected to be good because the number of engineering graduates should be in rough balance with the number of job openings over this period. Expected changes in employment and, thus, job opportunities vary by specialty. Projections range from a decline in employment of mining and geological engineers, petroleum engineers, and nuclear engineers to much faster than average growth among environmental engineers.

The number of students graduating with engineering bachelor's degrees has declined steadily for the past 17 years. Engineering graduates peaked at 77,572 in 1985, before decreasing in the years following. In 1998, only 60,914 engineering degrees were conferred.

The U.S. engineering workforce is predominantly white male and is aging rapidly. Over the last 15 years, the total number of individuals choosing engineering studies and careers has been decreasing. Of those students who initially choose engineering coursework, even fewer actually graduate with engineering degrees. This decline in the number of students in the engineering pipeline, coupled with increasing rates of retirement among engineers trained in the early 1960 s, points to a potential resource crisis. Current enrollment trends suggest that the United States may experience a serious shortfall in the number of engineers needed to fill jobs within the next decade.

Proceedings of the 2005 American Society for Engineering Education Annual Conference and Exposition. Copyright (C) 2005 American Society for Engineering Education 
Our nation seems to have an untapped resource ready to respond to this need. More than half our population is female, but fewer than 20 percent of the college students who choose to study engineering are female. And beyond college the numbers are worse. There are proportionately fewer women in engineering than in all other scientific or technical fields (except physics), and women constitute less than nine percent of the engineering workforce. In fact, many of the women discussed here are of a segment of the future workforce called the "Netsters" or "Millennials." With this new cohort entering the workforce, it is important to consider the different generational groups participating in the workforce today. In addition, for the future of engineering education, one must consider the Millennial values, beliefs, and world views so as educators, we can motivate them towards an engineering education.

\section{Generational Differences}

- People born between 1922 and 1943, we'll refer to them as Veterans, were children of the Great Depression and World War II. They lived through the Korean War and are recognized typically for their strong traditional views of God, family, and country. Their core values include respect for authority, loyalty, hard work, and dedication.

- People born between 1943 and 1960 - Baby Boomers - did not experience the same difficulties as their parents. They grew up during a time of economic growth and prosperity. Major influences in their lives include; the civil rights movement, women's liberation, the space program, the Cold War, and the Vietnam War. Their core values include; health, personal gratification, and material wealth. When asked, most Baby Boomer are optimistic and believe their generation changed the world.

- Generation X-ers (ie, people born between 1960 and 1980) sometimes are referred to as the misunderstood generation. They are the product of self-centered, workdriven Baby Boomer parents. Watergate, the advent of MTV, single-parent homes, and latchkey experiences played influential roles in their development. They were the first generation to embrace the personal computer and the Internet. They welcome diversity, are motivated by money, believe in balance in their lives, are self-reliant, and value free time and having fun.

Values, Beliefs, and World Views of Netsters

- Millennials, --are those people born between 1980 and 2000. They have no recollection of the Reagan era, do not remember the Cold War, and have known only one Germany. Their world has always had AIDS, answering machines, microwave ovens, and videocassette recorders. This generation includes more than 81 million people, approximately $30 \%$, of the current population. (4) They are greater in number than the Baby Boom generation. The Millennials will enter the workforce in large numbers as the Baby Boomers did, and they will influence changes in the work environment, just as the Baby Boomers did in the past. 
A survey of 27,000 12- to 19-year-olds revealed characteristics of the Millennial generation, including that they are

* self-reliant--they take responsibility for their own success independent of others;

* family-oriented--they rely on family as a sanctuary against the difficulties of life;

* brand-conscious--they place high value on brand name identification (eg, clothing);

* consumerist--Nexters shop, but they will not buy things that don't meet their needs and are skeptical of slick marketing promotions;

* mobile--Nexters promise to be the most mobile generation ever and already travel on the Internet;

* addicted to the media--it is not uncommon for Nexters to do homework, listen to a compact disc, watch television, and communicate online at the same time;

* fun-seeking--still mostly kids, they do not become bored because they have many options; and

* hopeful--they are not pessimistic or cynical but optimistic, and they expect to be happy adults. (4)

An expert in generation in the workplace, Dr. Marilyn Moats Kennedy, shared some of the following information in the keynote address at the 2004 Conference on Industry and Education Collaboration [7]:

Millennials expect to achieve academically. They have grown accustomed to standardized testing. Generationally, they tend to have high personal expectations to meet goals and develop unrealistic expectations to achieve those goals. They tend to enjoy collaboration and are technically-savvy. The Millennials value opportunities for mentoring and building on their skills.

In addition, this generation requires more direct "cut to the chase" communications style and enjoy participating in major organizational decisions as much as possible [3]. The Millennial generation grew up in an era of unpredictable changes (extreme technological advances, schoolyard violence, multiculturalism), so they have a need to change and adapt for survival [6].

How will an educator translate this generational profile to the classroom and attract these students to engineering and science careers? The answer to the alarming drops in engineering and science program enrollments may very well depend on the answer to this all important question.

Proceedings of the 2005 American Society for Engineering Education Annual Conference and Exposition. Copyright (C) 2005 American Society for Engineering Education 


\section{Suggestions}

Most research on the millennial generation offers only a glimpse of this cohort as the oldest is in college at the present. The following suggestions, based on the current knowledge base and research on this generation, will allow engineering and science educators, from K-12 to higher education, to consider millennial learning styles and preferences when preparing curriculum. Optimal learning outcomes and promotion of engineering and science education to the millennial generation could be the catalyst that increases the future enrollments in engineering and science education and encourages millennials to make engineering and science career choices. Based on research and what is known about this generation, the following suggestions are offered:

1. This generation looks at self-improvement as increasingly important as opposed to job security. "The world will always need engineers" will not be valued by this generation. As suggested by the above statistics, promotion of career choices in engineering and the sciences to the millennial generation is critical for future success. If millennials value "parallel career" educators will need to promote engineering and science parallel career opportunities. Educators will need to demonstrate the value of engineering and science careers as careers that will require lifelong learning and training.

2. Educators must be willing to present information and design education so to appeal to millennial learning styles. Communicating cross-generationally means packaging the message in several ways so that every hearer understands [7]. Technology must be employed in the classroom and utilized to offer courses differently. If millennials do not see state-of-the-art technology in the classroom and laboratory educational setting, what would their expectations be for a career in engineering and the sciences? Educators may wish to engage this generation by having them utilize their technological skills in the classroom and allowing flexibility and opportunities to change the educational experience so it is motivating for their generation. Millennials expect flexibility and if engineering and science educators are not creative and flexible in course offerings, the message is that careers in these disciplines will be equally inflexible. The technosavvy millennial generation, as a whole, will be motivated by opportunities for creativity and challenging learning environments. The open-ended access to information, the ability to tailor the paths to learning, and the possibility of continuous and instantaneous performance assessment, offer a great deal of flexibility both in the design of curricula as well as in the method of delivery.

3. Involve students in organization and association memberships. Their participation in student association memberships, such as ASEE for example, will allow for students to feel more involved with their chosen career and will offer opportunities for achievement of their goals and values of mentoring and collaboration with other students with like interests.

Proceedings of the 2005 American Society for Engineering Education Annual Conference and Exposition. Copyright (C) 2005 American Society for Engineering Education 
4. Provide mentorship and team support for the millennial generation. Educators will serve as mentors to Millennial generation student. In addition, higher educational institutions should provide mentoring with engineering and science graduate or upper-level students partners. Millennials value mentoring and this will encourage more long-term commitment to engineering and science careers. Student team support will be motivating for the millennial generation student as well.

\section{Conclusion}

The bad news is that over the last 15 years, the total number of individuals choosing engineering studies and careers has been decreasing. The decline in the number of students in the engineering pipeline warns of a potential resource crisis. Current enrollment trends suggest that the United States may experience a serious shortfall in the number of engineers needed to fill jobs within the next decade.

The good news is that our nation seems to have an untapped resource ready to respond to this need. As the Millennial generation enters college, graduates and enters the world of work, there is opportunity for educators to attract this generation to careers in engineering and the sciences. For the future of engineering education, one must consider the Millennial values, beliefs, and world views so as educators, we can motivate them towards an engineering education. The old days of the mindset, "if we offer it they will come" will not resolve the potential crisis. Engineering as a profession needs to promote itself on numerous levels. One avenue available is to seek to understand and promote engineering to the future generations, or specifically the millennial generation.

\section{References}

1. National Science Foundation/Division of Science Resources Statistics (2001). Survey of Graduate Students and Post-doctorates found that graduate student enrollment in the sciences and engineering fields.

2. U.S. Department of Education (2000). SOURCES: U.S. Department of Education, Completions Survey; and National Science Foundation, Division of Science Resources Statistics, WebCASPAR database system, http://caspar.nsf.gov.

3. Lancaster, L.C., \& Stillman, D. (2002). When generations collide. New York: Harper Business.

4. A Nation at Work. (2003). New Jersey: Rutgers University Press. Ed. Schaffner, H.A., \& VanHorn, C.E.

5. Understanding. (2001). Newport: TED Conferences. Ed. Wurman, R.S..

6. Zemke, R, Raines, C., \& Filipczak, B. Generations at work. New York: American Management Association; 2000.

7. Kennedy, M.M. (2004). Managing change: Understanding the demographics of the evolving engineering workforce: Conference for Industry and Education Collaboration; Keynote address. February, 4, 2004.

\section{Biographies}

Proceedings of the 2005 American Society for Engineering Education Annual Conference and Exposition. Copyright (C) 2005 American Society for Engineering Education 
BEVERLY J. DAVIS is an Associate Professor of Organizational Leadership at Purdue University's College of Technology. Currently she is Division Chair of the ASEE Manufacturing Division. Her research interests include technology and human behavior and workplace literacy.

JAMES MORGAN has been at the Princeton Plasma Physics Laboratory since 1996.

Princeton Plasma Physics Laboratory is a Collaborative National Center for plasma and fusion science. Its primary mission is to develop the scientific understanding and the key innovations which will lead to an attractive fusion energy source. During this time he has worked on and developed several outreach and educational endeavors for K-16, including the National Undergraduate Fellowship in Plasma Physics and Fusion Engineering, a 10-week summer research experience for undergraduates interested in plasma physics.

Proceedings of the 2005 American Society for Engineering Education Annual Conference and Exposition. Copyright (C) 2005 American Society for Engineering Education 